\title{
LINGUISTIC PERSONALITY IN UKRAINIAN \\ LANGUAGE EDUCATION OF DEAF EDUCATION DIRECTION
}

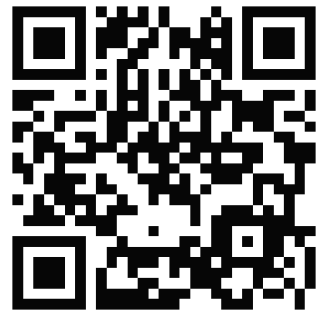

To cite this article:

\author{
Svitlana Kulbida, Dr. Sc., Prof. \\ Chief Scientific Officer, \\ Sign Language Training Department, \\ Mykola Yarmachenko Institute \\ of Special Pedagogy and Psychology, \\ National Academy of Educational Sciences of Ukraine, \\ Kyiv, Ukraine \\ svk5554@gmail.com \\ https://orcid.org/0000-0002-0194-3495
}

Kulbida, S. (2020). Linguistic personality in Ukrainian language education of deaf education direction. Education: Modern Discourses, 3, 131-142. https://doi.org/10.37472/2617-3107-2020-3-13

\begin{abstract}
The article is devoted to the disclosure and comparative analysis of the category of linguistic personality in the modern general and special language education of deaf education direction. Attention is drawn to the fact that the formation of a linguistic personality depends on many aspects. The specificity of the linguistic personality formation of a person with hearing impairment is central to the development of the scientific foundations of the special education system for people with hearing impairments ( $H$ 90, $H$ 91), which would be as adequate as possible to the methods and techniques of learning and usage the Ukrainian Sign language together with the Ukrainian language, taking into account the State Standard for Primary Education, the project of Basic State Standard for General Secondary Education. The author shows that the content of the linguistic personality of a hearing-impaired person is influenced by various factors. On the basis of the author's complex of the formative language education methodology, the tendencies of restructuring of the educational process are grounded, taking into account the current norms of the legislative base, development of new content of language training, the use of strategies, which generally contribute to the formation of a linguistic personality of a hearing-impaired person.

Key words: competence potential; deaf education direction; educational discourse; linguistics, linguistic personality of a hearing-impaired person; Ukrainian language; Ukrainian Sign language.
\end{abstract}

\section{INTRODUCTION}

Modern integrative science, which is able to describe and substantiate the mechanisms of language acquisition, to reveal the specifics of the use of these mechanisms in the educational environment, is language education. General language education is related to two disciplines - language didactics and language teaching, which ultimately consider the central category - a person's ability to master the language and use the language as an accessible and understandable means of communication. Ascertaining representations of scientific reflection by B. Belyaev, 
O. Bilyaev, I. Bim, A. Bogush, M. Vashulenko, E. Vetrogradska, O. Goroshkina, N. Ermak, S. Yermolenko, L. Kazantseva, L. Kardash, O. Lyubashchenko, L. Matsko, S. Omelchuk, M. Pentylyuk, O. Pershukova, K. Plysko, O. Savchenko, O. Semenog, L. Skurativsky, O. Khoroshkovskaya and others only confirm these positions. Language education reserchers consider as one language - the basis of personality development in the educational process, and two languages (V. Buryak, S. Goncharenko, V. Redko, O. Semenog, O. Khoroshkovska, etc.). To different results of educational and communicative activity in modern language education of consideration the basic provisions of different models of two languages the central problem of linguistic personality is also added (I. Gulakova, N. Duzhyk, V. Karasyk, Y. Karaulov, N. Mayboroda, S. Omelchuk, L. Struganets, T. Yanko, etc.). In our view, this industry has prospects for learning and using Ukrainian Sign language (USL) together with Ukrainian language (UL) in bilingual educational and communicative activities, as it enhances the possibilities for visual continuous mastering of the language and speech flow of information with the help of a hearing-impaired person's (HIP) intact analyzer - educational recipients in terms of educational discourse. Over the last decade, USL has ceased to be a simple addition to addressing extra-curricular information problems, related to information support. Currently, theories, concepts, technologies are developing that attempt to solve problems and issues that are at the intersection of linguistic, pedagogical, psychological components with a focus on USL.

Language education of deaf education direction as a science comprehends, describes the structure of the linguistic personality of the HIP, as the acquirer of education, as a competent speaker, substantiates the conditions and patterns of its development as a desirable result in the process of mastering the language(s), defines the indicative characteristics of the levels of mastery the sign speaking communicative competence in different models of bilingual learning, provides indicative strategies for gaining the competent experience of two communities and two cultures.

On the other hand, like any other branch of knowledge, language education studies the problems of analysing, modelling the processes of mastering each language, and managing those processes. For deaf education professionals engaged in didactic issues, the ability to communicate in a language(s) serves as a strategic goal of learning, taking into account the specific conditions of the developing linguistic personality of the HIP and the educational discourse of special education.

Turning to the modern language education of deaf education direction is also important for developing the scientific basis of the special training system effectiveness for HIP ( $\mathrm{H} \mathrm{90,} \mathrm{H} \mathrm{91),} \mathrm{which} \mathrm{would} \mathrm{be} \mathrm{as} \mathrm{adequate} \mathrm{as} \mathrm{possible} \mathrm{to} \mathrm{the} \mathrm{approaches,} \mathrm{functions,} \mathrm{conditions}$ of educational discourse in the organization of bilingual learning, assessment, methods of studying and using USL together with UL according to the State Standard for Primary Education (2018), and also presented for discussion the project of the Basic State Standard for General Secondary Education (Derzhavny standart bazovoi serednyoi osvity (2020).

The aim of the paper is to make a comparative analysis of the problem of the linguistic personality in general and special literature, as a competent speaker, and to explore the peculiarities of understanding the linguistic personality of a person with hearing impairment in the educational discourse in the lessons of the language cycle.

\section{METHODOLOGY}

In the process of research we used a set of methods: theoretical retrospective systematic analysis of language education literature, comparison, generalization of the obtained provisions, extrapolation of theoretical and research data in modelling, formulation of 
definitions; empirical: systematic observation and study of students taking into account the thesaurus of the individual, the picture of the world, motivational factors, identifying the peculiarities of developing the content of teaching the subject at the empirical and theoretical levels, streamlining the system of language(s) knowledge, conclusion. A complex of forming language education techniques, which is described in detail and presented by author's monograph (Kulbida, 2019).

\section{LITERATURE REVIEW}

Understanding of "linguistic personality", "competent speaker" in general language education. The range of studies of the problem of "linguistic personality" in general language education is historically determined, has a chronological development, and occurs from single to widespread applications. For the first time the term "linguistic personality" is found in the works of the German linguist L. Weisberger (1929), the Russian linguist V. Vinogradov (1930). G. Bogin called the "linguistic personality" the central concept of language education (Bogin, 2011: p. 275), also served by numerous foreign scientists (Firth, 1950: p. 34; Valencia, Karaulov, Krasnykh, Sevilla-Troike, Gorter, Cenoz, 2016: p. 16; Fesenko, 2013; Dewaele, Furnham, 2000: p. 6; Milano, 2006: p. 23; Rosch, Lloyd, 1978: p. 201; Wierzbicka, 1991: p. 18, etc.), Ukrainian (Borodina, 2005; Bogush, 2007, 2008; Buchanska, Kalenyuk, 2005; Pentylyuk, 2011; Omelchuk, 2019, etc.), psycholinguists based on the fundamental conceptual positions of L. Vygotsky, O. Leontiev, O. Bozhovich (Zasyekina, 2007: p. 83) and linguists (Azarova, 2018: p. 171; Ermolenko, Matsko, 1995: p. 11; Mykhalevich, 2011: p. 20; Omelchuk, 2019: p. 12; Plusch, Selivanova, 2016: p 134; Skurativsky, Yushchuk, 2014: p. 56, and others).

In today's context, a rather broad typology has been used in understanding the meaning of the term "linguistic personality", which depends on the aspect of research, consideration of generality and specificity, in particular, more than a result of personality formation. For example, according to the definition of Ukrainian linguists S. Ermolenko, L. Matsko, "a linguistic personality is that native speaker who not only possesses the sum of linguistic knowledge (knows concepts and rules) or reproduces language activity, namely, one who has developed skills of active work with the word" (Ermolenko, Matsko, 1995: 35).

According to M. Pentylyuk, who explores concepts from the point of view of subjectsubject relations of the educational process participants, "a linguistic personality is a person who possesses the riches of the language, produces it in different life situations and respects, cares for its preservation and development, that is why a student should become such a person while studying at school" (Pentylyuk, 2011: p. 59).

The linguistic personality in each specific period of development of society bears the imprint of the public and social environment of a certain territory, peculiarities, customs, and traditions of educational influence both in the culture of the people, community, and family, which is served by the language system. According to O. Selivanova, a linguistic personality is an "immanent feature of a person as a native speaker and communicator, characterizing his or her linguistic and communicative competence and their realization in the processes of production, perception, understanding, and interpretation of verbal messages, texts, as well as in communicative interaction" (Selivanova, 2016: p. 445). The level of linguistic competence stimulates the linguistic personality to improve the language. The well-known scientist A. Bogush states that the linguistic personality is formed in a particular society exists in the space of a particular culture, which is reflected primarily in the language, in the forms of social national consciousness (everyday, civic, scientific, legal, etc.), in the subjects of material national culture, in the behaviour, moral standards and norms of speech etiquette of the people who use these norms" (Bogush, 2007: p. 29). The refined modern version of the 
term "linguistic personality" - "highly developed personality, a native of both national-speech and human culture, who possesses socio-cultural and linguistic stock, freely communicates in the native, state and other languages in the multicultural space, adequately uses the acquired multicultural, skills in the process of intercultural communication with different categories of the population" (Bogush, 2008: p. 36).

In general methodological science, we find the term "national-linguistic personality" (Bilyayev, Omelchuk, 2019: p. 39). It takes into account the principle of active communication, the ability to produce expressions of varying degrees of complexity and saturation of nationally labelled units, peculiar to language designations, forms, combinations, syntactic constructions. Linguistic is a highly developed personality, who possesses socio-cultural and linguistic information stock, can adequately apply it in the process of communication with different categories of communicators.

The current understanding of the "linguistic personality" as an "independent user", proposed by the Council of Europe, implies a certain sufficient level when the student possesses a complex of knowledge, skills, and competences that, collectively, enable him to respond adequately in difficult social and communicative situations. In particular:

a) basic knowledge of the language system and the skills of adequate using the language means during communication;

b) communicative skills that provide the ability to understand (receptive level) and generate (productive level) utterance in accordance with a particular field (topic, situation) communication, speech task, communicative intent, and also taking into account the sociocultural characteristics of the persons, whose language is being taught (Lokshyna, 2019: p. 22).

As we have seen, the discourse on the use of definition has various aspects.

\section{MAIN RESULTS}

Features of understanding the linguistic personality of a person with hearing impairment in educational discourse in the lessons of the language cycle.

Analysed views of scholars and official organizations make it possible to consider a linguistic personality in a language education-focused aspect, focused more on a linguistic personality. However, it is worth noting that a hearing-impaired person, due to objective circumstances, is a bilingual personality whose development and formation are by means of two languages (Ukrainian sign and Ukrainian languages). Ukrainian linguist F. Batsevych differentiates two concepts: "linguistic personality" and "secondary linguistic personality". In the first case, it is "a person who shows themselves as having a good means of the mother tongue language code in various types of communicative situations", in the second case - "a person involved in the culture of the people whose language is being learned, a person who can implement in the dialogue of cultures" (Batsevych, 2007: p. 16). This view is confirmed by Jose Fco. Valencia \& Jasone Cenoz, 2010 (Valencia \& Cenoz, 2010: p. 433); Jasone Cenoz та Yolanda Ruiz de Zarobe, 2015 (Cenoz \& Zarobe, 2015: p. 1).

In Ukrainian language education of deaf education direction, the problem of linguistic personality of the HIP as a competent speaker has arisen at a conceptual level due to understanding and continuation of traditions of North American and European schools (Bazoev, Dimskis, 2010: p.211; Zaytseva, Rassell, 2005: p. 94; Kobel, 2005: p. 26; McQuarrie, 2008: p. 59; Parrila, Odishaw, Barber, Hirschfeld, Williams, 2010: p.11; etc.) of the sociocultural context of deafness, as opposed to the biological-medical context. This is confirmed by the concepts of Sign language in Ukraine (2009) (Kulbida \& Chepchina, 2009: p. 3-7), bilingual training using USL (2011) S. Kulbida, I. Chepchina, N. Adamyuk, N. Ivanyusheva, N. Zborovskaya, etc (Kulbida, Chepchina, Adamyuk, Ivanyusheva, Zborovskaya, 2011: p. 5). 
In our view, a comprehensive study of the linguistic personality of the HIP as an education applicant should take into account a number of context systems - dynamic constituents of real reality and, at the same time, relevant for a given category of persons. The most important of them are:

- taking into account the critical period of language development through any modality under the necessary and important condition of sensory perception of the features capabilities of the preserved compensatory systems (for deaf children it is sign language);

- access to information in an easy and convenient way to ensure communicative needs;

- establishing and maintaining interpersonal relationships with others, acquiring social experience characteristic of peers;

- mastering the second language on the basis of the first language, whose competence should be at least A2 level;

- organization of bilingual communicative activities in the system of accompanying mentors who are able to maintain and develop gradual levels of competence development of bilingual personality - sign speaking communicative competence, cognitive (ability to think, information processing), and communicative characteristics (Kulbida, 2016).

The linguistic personality of the HIP originates and develops in the space of cultural values, social consciousness, and stereotypes of parents (at different levels from everyday to scientific), the communicative environment of linguistic forms of a particular language, norms of behaviour. Such linguistic personality bears the imprint of the communicative environment, the traditions of development, and upbringing in the family, the consequences of the parents' chosen path. Gradual levels of competence stimulate the linguistic personality to improve the basic (first) language. Therefore, the content of the linguistic personality of the HIP is influenced by value settings of family education, beliefs of parents, communicative environment, peculiarities of communicative activity, linguistic and speech representations in the first language, which provides an understanding of the surrounding world; cultural patterns of language acquisition, its forms from mentors, the rules of communicative behaviour, and the skills to use when communicating with different communicators.

The linguistic personality of the HIP is considered and understood as a personality characterized by a complex of typical language traits of the student at three levels:

- linguistic-semantic (internal lexicon of personality), presented in the language consciousness in the form of lexical-semantic groups, grammatical means, signs, sentences. This is the level of everyday speech based on the knowledge of the language system in the understanding of latent spontaneous learning, intuitive sensation, and determined by the regularities of the psycho lingual period of development. The concept of "knowledge of the language system" includes not only the retention of the learning units of the language (signs, words, their morphemes, forms, grammatical, kinetic, syntactic constructions, etc.) but also awareness of the norms of their use, the ability to use the units of language during speech perception or production. For lexical units of pronounced semantics include the names of realities (definitions of objects, phenomena that characterize the culture of the deaf community, and are absent in the culture of the hearing community), connotative vocabulary (concepts that are essential in essence, but differ in cultural associations), derivations (connected the signs), an idiomatic vocabulary that reflects the peculiarity of understanding the simplicity or inferiority of the native speaker. In structural linguistics, it is customary to proceed from the meaning of sign as a linguistic sign, which denotes an object not directly but through a signifier (a generalized, abstract imaginary image in a native speaker), which acts as an object of thought, as a result of the production of a linguistic unit (Kulbida, 2011).

- linguistic-cognitive, represented by the thesaurus of the individual. An orderly system of the "linguistic picture of the world" (Gural, 2008; Gural, Smokotin, 2014) includes images, 
concepts, symbols, phrases that are formed in each linguistic personality of the HIP. The concept of linguistic personality is the fixed connection of language with its individual consciousness, with its outlook. Every personality manifests itself and its subjectivity not only through subject activity but also through communication, which is impossible without language and speech. The language of personality reflects its own inner world, serves as a source of knowledge about it. Moreover, it is obvious that a person cannot be learned beyond language, because, even in simple life situations, it is difficult to understand what kind of person it is until we see how and what it speaks. Nevertheless, it is also impossible to "consider language in isolation from man" (Zasyekina, 2007: p. 83), because without a person who speaks a language, it remains nothing more than a system of signs. O. Mazepova, 2014, who argues that a person can only be spoken as a linguistic personality embodied in language, confirms this view (Mazepova, 2014: p. 280).

- motivational-pragmatic (the level of activity-communicative needs) is determined by the peculiarities of the communicative activity of the individual, the intellectual sphere, interests, motives. In the learning process, the student is in a certain social environment, in contact with his teacher and classmates. Such influence shapes his ability to study and evaluate the qualities of other people and the team as a whole, contributes to the social experience of communication with people. The social and ethical standards of the two communities served by students, hearing teachers, non-hearing teachers should be clear, informative, and unrelated, in no way discriminatory. It is not permissible to ignore the rights of one another at the expense of the other, which not only does not contribute to the formation of socially significant norms of the motivational and pragmatic level, behavior of the language personality of the HIP but also prevents the creation of a mutually friendly atmosphere of coexistence in the team, community, society.

All three levels depend on the conditions of the communicative environment of the educational discourse, the specifics of the use of the visual-move and (or) articulation systems in the perception and production of speech, the use of language(s) acquisition strategies, the mentors' awareness of the role and importance of mono- or bilingualism.

The individual gradual development of personality masters different levels of experience formation in the form of linguistic and speech competences from the simplest to the most difficult - competence potential. Mastering linguistic knowledge develops linguistic sensations, forms linguistic understanding, linguistic guidelines, forms the creation of one's linguistic consciousness - "knowledge, feelings, evaluations, and guidelines about language and linguistic reality" (Seligei, 2012: p. 10).

The manifestations of the linguistic personality of the HIP in the field of education are called educational discourse. Levels of the linguistic personality of the HIP allow for a more comprehensive and multifaceted representation of personality through a central component the language and educational discourse of bilingual learning.

Based on the described structural levels, we consider the linguistic personality of the HIP as a set of linguistic abilities and linguistic behavior of the bilingual, conditioned by sociocultural, psychological and pedagogical conditions of formation and development, which are manifested in his individual style - knowledge of the language system, world picture, forms of speech, language priorities, and motivation we raise the issue of the formation of such personality in special institutions of general secondary education (H 90 and $\mathrm{H} 91$ ).

The modern school now faces the challenge of effectively developing the linguistic personality of the HIP in educational discourse. For this purpose, educational standards determine the necessary competency frameworks, and educational institutions - the ways of their formation and development.

In the context of the reform of the education system, there is a gradual adjustment of the focus of modern special institutions of general secondary education $(\mathrm{H} \mathrm{90,} \mathrm{H} \mathrm{91)}$ on the 
formation of the language personality of the HIP - "competent speaker" - the applicant for education within a clear mechanism of the educational policy of the state, taking into account three modern approaches: oriented, socio-cultural, competent. This is confirmed by updated legislation and regulations, state standards, the content of education (standard plans, software and methodological support, textbooks, manuals), which are obliged to close or narrow the gap between scientific theory and existing practices in the implementation and provision of modern educational discourse, which are aimed at the study of UL and USL on the development of the linguistic personality of the HIP, communicative competence, national consciousness, tolerance, nobility.

The essence and structure of the key competence "learning ability" is fully presented by O. Savchenko, 2015, as a "key competence of a junior student" (Savchenko, 2015: p. 5).

The indicative description of the gradual levels of the competence potential formation of the language personality of the HIP, developed in the project of State Standard of Basic Secondary Education, is given.

The competency-based approach to education presented is new to the Ukrainian specialized general secondary education institutions ( $\mathrm{H} \mathrm{90,} \mathrm{H} \mathrm{91)}$, as it has so far focused on the accumulation of knowledge, monolingual speaking skills, and partly on the automation of writing, $\mathrm{ABC}$ speaking or verbal skills. The training programs did not include the use of translation tools, work on the development of linguistic personality, the ability to navigate different translation strategies, etc. (Kulbida, 2019b: p. 142).

Therefore, the author has set the aim of creating new textbooks of the language cycle, in particular, "Ukrainian language" for elementary school (Kulbida, 2018a, 2018b, 2019c, 2019d) and $5^{\text {th }}$ grade, based on the principles of progression of learning goals and competency potential of the linguistic personality of the HIP, taking into account the opportunities and abilities.

Each textbook defines: a set of knowledge, abilities, skills, gradual levels of competences, ways of linguistic behavior, presents the practical aspect of strategies for mastering linguistic and speech material, provides the expansion of functions of verbal language based on sign language, allows developing patterns of Ukrainian communication, to understand common and excellent in two languages during studying specific topics.

For students with hearing impairments, there is a need to "learn and perceive the national identity of the language at the level of the sections of lingual (meta-linguistic) knowledge of the first and second languages" (Zalevska, 2007: p. 211). In this regard, the primary purpose of language learning both first- and second-time for students with hearing impairments in educational institutions is to build their competency potential as the nucleus of the linguistic personality.

The formation of competency potential is an important didactic feature of modern textbooks, since theoretical information, language rules, generalizations are presented not so much for memorization, but to a greater extent, for practical mastering, especially in the conditions of initial learning, when learning begins to form be sure to consider the area of immediate development. The practical focus is, first, on developing not so much knowledge about the language, but to extend language skills, namely: constructing sentences different in structure and purpose for expression; correctly form a sing (word) and connect with other members; build a sign combination (phrase), adhere to norms of compatibility (kinetic, phonetic, graphic, grammatical, structural) in order to prevent possible difficulties of learning.

The important role of the presented strategies as algorithms of communicative activity for students to perform exercises and tasks. The clarity and uniqueness of the wording are directed at the pupils, making them accessible for children's perception and understanding. Improved system of symbols. 
Levels of competence potential formation of the linguistic personality of the HIP

\begin{tabular}{|c|c|c|c|}
\hline \multicolumn{4}{|c|}{ Levels of competence potential formation of the linguistic personality of the HIP } \\
\hline & & The First Language & The Second Language \\
\hline \multirow{2}{*}{ 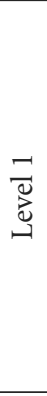 } & A1 & $\begin{array}{l}\text { understands and can use common expressions and simple } \\
\text { phrases necessary to fulfill specific needs, including introducing } \\
\text { themselves or another person, asking and answering questions } \\
\text { about themselves (place of residence, family, personal effects, } \\
\text { etc.); can interact at a simple level. }\end{array}$ & \multirow{6}{*}{$\begin{array}{l}\text { Not lower A2. } \\
\text { Imitation. Perception, } \\
\text { understanding, imitation } \\
\text { of lexical units and speech } \\
\text { patterns, their assimilation, } \\
\text { and reproduction without } \\
\text { changes. } \\
\text { Reproduction of assimilated } \\
\text { speech samples with minor } \\
\text { changes. } \\
\text { Generalization. The } \\
\text { production of utterances by } \\
\text { the syntactic reorganization } \\
\text { of the learned speech patterns } \\
\text { and by analogy. Production } \\
\text { of statements due to } \\
\text { morphological reorganization } \\
\text { of the learned speech samples } \\
\text { and by analogy use the full } \\
\text { language experience of the } \\
\text { first language to master the } \\
\text { second language; develop } \\
\text { forms of speech (accessible } \\
\text { and easy to master), to } \\
\text { compare, contrast linguistic, } \\
\text { speech phenomena, to } \\
\text { distinguish between common } \\
\text { and distinct concepts for } \\
\text { the purpose of conscious } \\
\text { learning, to shape the world } \\
\text { picture by means of language, } \\
\text { to stimulate communicative } \\
\text { intentions in mastering } \\
\text { gradual levels of language, } \\
\text { to use memos as specific } \\
\text { algorithms for action. }\end{array}$} \\
\hline & $\mathrm{A} 2$ & $\begin{array}{l}\text { understands and can use individual phrases and commonly } \\
\text { used phrases related to specific activities and practical daily } \\
\text { skills (information about themselves, family, location, walk, } \\
\text { trip, etc.); can communicate in situations where the simple and } \\
\text { direct exchange of information on familiar topics is required. }\end{array}$ & \\
\hline \multirow[b]{2}{*}{$\frac{\sim}{\stackrel{d}{\leftrightarrows}}$} & B1 & $\begin{array}{l}\text { understands the main content of clear, standard information } \\
\text { on topics (close and often used) in training, during leisure } \\
\text { time, etc.; simply and clearly expresses personal preferences, } \\
\text { interests; describes personal experiences, events, dreams, plans, } \\
\text { explains his attitude, motivates. }\end{array}$ & \\
\hline & B2 & $\begin{array}{l}\text { understands the basic ideas of a complex text on both a } \\
\text { specific and abstract topic, gradually discusses and presents } \\
\text { arguments; be able to communicate with native speakers } \\
\text { with a degree of speed and spontaneity that enables regular } \\
\text { relations with them without causing difficulty to either party; } \\
\text { can express clearly and in detail on many topics, including } \\
\text { expressing one's opinion on a particular issue, outlining the } \\
\text { advantages and disadvantages of different positions. }\end{array}$ & \\
\hline \multirow[t]{2}{*}{$\frac{m}{\stackrel{d}{d}}$} & $\mathrm{C} 1$ & $\begin{array}{l}\text { understands a wide range of complex and large texts, } \\
\text { recognizes the hidden content in them; can express quickly } \\
\text { and spontaneously without noticeable complications } \\
\text { associated with the search for a means of expression, easily and } \\
\text { accurately use the language in communication, training and } \\
\text { achieve communicative goals; clearly, structured and detailed } \\
\text { in complex topics, demonstrates knowledge of grammar rules, } \\
\text { syntax. }\end{array}$ & \\
\hline & C2 & $\begin{array}{l}\text { easily understands virtually anything that perceives (hears or } \\
\text { sees), reads, can summarize information from various sources, } \\
\text { can make a reasoned statement in a logical, coherent form, and } \\
\text { express spontaneously, quickly and accurately, conveying the } \\
\text { thinnest meaningful shades of information. }\end{array}$ & \\
\hline
\end{tabular}

Important, in our view, are the functions of the textbook, which are intended to help to accumulate information resource, namely:

1) to show clearly for students the samples in mastering the Ukrainian language;

2) to realize the value of intercultural communication in their immediate environment (in class, school, family, etc.);

3) increase motivation to learn the language;

4) to form self-esteem;

5) to help to test the level of command of the language (languages) and to compare it with the European norms;

6) to choose (together with the teacher) the most rational ways of improving their knowledge and skills. 
In fact, at the language cycle lessons in primary school, there is a basic formation of the language personality of the HIP at different levels as:

- communicator - a speaker who produces texts of different forms, styles, types, and genres of speech;

- recipient - the perceiver and the reader who reproduces the visual-move and graphic expressions of others;

- informant - a speaker who transmits messages for different purposes.

Based on systematic observations and study of the teaching and learning experience for the development of linguistic personality, the following steps are generally taken in the educational establishment. Teachers cooperate in all subjects, aiming to identify and correct mistakes in the forms of UL (31.1\%), develop sets of tasks for classroom and extracurricular work taking into account the individual achievements of each student (51.7\%), develop thematic sign dictionaries, dictionaries (sing-verbal, verbal-sign) $(17.2 \%)$.

Thus, the gradual process of forming the linguistic personality of the HIP is realized in specially created conditions of educational discourse, psychological and pedagogical support of specialists of the educational institution.

According to the practice of special education ( $\mathrm{H} \mathrm{90,} \mathrm{H}$ 91), understanding the linguistic personality of the HIP requires both clarification and refinement, given the different levels of competency potential in two languages. In order for the proposed positions of modern language education of deaf education direction to promote the educational tasks, it is necessary to clearly understand the role, theoretical and practical significance, structure, conditions of educational discourse in the formation of the linguistic personality of the HIP.

\section{CONCLUSIONS}

Given the presented, discursive use of the definition of "linguistic personality" has different aspects. Such an integrative notion of the term has certain structural elements relating to language, speech, and extralinguistic phenomena.

The representation of a linguistic personality of the HIP is complex, taking into account the system of contexts relevant to the particular category of persons.

The problem of the formation of a linguistic personality of the HIP in the modern language education of deaf education direction is connected with the modern tendencies of the restructuring of the educational process, taking into account the normative-legal legislation, strengthening the role and importance of USL together with the UL in educational discourse.

This concerns the need to strengthen the practical direction of the content of language learning, the development of students' ability to acquire information, present information in two languages, to be able to implement it in everyday life. It is appropriate to prepare a competent speaker with an appropriate level of competency potential based on a system of knowledge of the language(s). Students learn language systems, particularly in the language cycle lessons, develop language skills, linguistic concepts, improve language and communication culture, translational strategies that contribute to the formation of the linguistic personality of the HIP.

Turning their views on the linguistic personality of the HIP should deepen the foundations of linguistic theory on the study of periods of evolution of the "linguistic identity of the deaf student", the educational discourse of intercultural communication, the "collective linguistic personality" and serve as the basis for new research.

We see the prospect of further research in the development of a special institution system of work for the formation of a linguistic personality of the HIP (considering the needs, perspectives, levels of mastery of each language, linguistic environment, adequate conscious choice, motivation, self-concept) taking into account a person-oriented, competent, system, communicative activity approaches to learning. 


\section{REFERENCES}

Azarova, L. (2018). The Concept of Language Personality in Linguistics. Annales Universitatis Mariae Curie-Sklodowska, sectio FF, Philologia, 35. http://dx.doi.org/10.17951/ ff.2017.35.1.169

Batsevych, F. (2007). Slovnyk terminiv mizhkulturnoi komunikatsii [Glossary of terms of intercultural communication]. Kyiv: Dovira. (in Ukrainian)

Bogin, G. (2001). Obretenie sposbnosti ponimat: Vvedenie v Hermenevteku [Acquisition of the Ability to Understand: Introduction to Hermeneutics]. Retrieved 2020 from: http:// sbiblio.com/BIBLIO/archive/bogin_obretenie/11.aspx (in Russian)

Bogush, A. (2007). Doshkilna lingvodydactyka: teoriya i metodyka navchannya ditey ridnoi movy : Pidrychnyk [Preschool Language Education: Theory and Methods of Teaching Mother tongue: A Textbook]. A.M. Bogush, N.V. Gavrysh (Eds.). Kyiv: Publishing house «Slovo». (in Ukrainian)

Bogush, A. (2008). Formuvannya movnoi osobystosti na riznyh vikovyh etapah: monohrafiia [Formation of linguistic personality at different age stages: monograph]. Odesa: PNTS APN Ukrainy. (in Ukrainian)

Borodina, N., \& Kalelyuk, S. (2015). Formuvannya movnoi osobystosti uchniv yak providne zavdannya movnoi osvity [Formation of language personality of students as a leading task of language education]. Studia methodologica, 41, 79-84. (in Ukrainian)

Cenoz, J. \& Zarobe, Y. (2015). Learning through a second or additional language: contentbased instruction and CLIL in the twenty-first century INTRODUCTION. Language Culture and Curriculum, 28(1), 1-7. http://doi.org/10.1080/07908318.2014.1000921

Chaudron, C. (1988). Second language classrooms: Research on teaching and learning. Cambridge [UK]: Cambridge University Press. Retrieved 2020 from: http://hdl.handle.net/2027/ heb.31753.0001.001

Derzhavny standart bazovoi serednyoi osvity (2020) [State standard of basic secondary education (project)]. Retrieved from https://zakon.rada.gov.ua/laws/show/898-2020$\%$ D0\%BF\#Text

Dewaele, J. M. \& Furnham, A. (2000). Personality and speech production: a pilot study of second language learners. Personality and Individual Differences, 28(2), 355-365.

Firth, J. R. (1950). Personality and language in Society. 37-52. https://doi.org/10.1111/j.1467954X.1950.tb02460.x

Gubar, O. (2015). Fenomen movnoi osobystosti v suchasnomu osvitnyomu prostori: teoretychnyy aspekt [The phenomenon of linguistic personality in the modern educational space: a theoretical aspect]. Aktyalni putannya korektsiynoi osvity (pedagogichni nauky): zbirnyk naukovyh prats, 6, 84-95. (in Ukrainian)

Kazantseva, L. (2014). Language education foundations of teaching Ukrainian as a State language to preschool children in the context of modern scientific paradigms. Osvita $i$ pedagogichna nauka, 1(162). http://doi.org/10.12958/EPS.1(162).Kazantseva_L_I (in Ukrainian)

Kontseptsia "Nova ukrainska shkola” (2016) [New Ukrainian School Concept]. Retrieved from http://zakinppo.org.ua/images/2017/docs/10/konczepcziya.pdf

Kulbida, S. \& Chepchina I. (2009). Proekt kontseptsii zhestovoi movy v Ukraini [The draft concept of sign language in Ukraine]. Osoblyva dytyna: navchannya i vyhovannya, 3(53), 3-7. (in Ukrainian)

Kulbida, S. (2011). Leksychne znachennya zhestu [The lexical meaning of the sign]. Zhestova mova i suchasnist, 6, 98-108. (in Ukrainian)

Kulbida, S. (2016). Formuvannya zhestomovnoi komunikatyvnoi kompetentcii - vid rozuminnya do zastosuvannya [Formation of sign speaking communicative competence 
- from understanding to application]. Osoblyva dytyna: navchannya $i$ vyhovannya, 1/77, 15-29. (in Ukrainian)

Kulbida, S. (2018a). Ukrainska mova. 4 klas: pidruchnyk dlya 4 klasu spetsialnyh zakladiv zagalnoi serednyoi osvitu (H 91) [Ukrainian language. Grade 4: Textbook for Grade 4 Special General Secondary Education (H 91)]. Kyiv: Lybid. (in Ukrainian)

Kulbida, S. (2018b). Ukrainska mova. 5 klas: pidruchnyk dlya 5 klasu spetsialnyh zakladiv zagalnoi serednyoi osvitu (H 90) [Ukrainian language. Grade 5: Textbook for Grade 5 Special General Secondary Education (H 90)]. Kyiv: Lybid. (in Ukrainian)

Kulbida, S. (2019a). Features of bilingual approach application in special institutions for deaf in Ukraine. Education: Modern Discourses, 2, 141-152. https://doi.org/10.32405/2617-31072019-1-17

Kulbida, S. (2019b). Lingvodydaktychni zasady vyvchennya ukrainskoi zhestovoi movy: monografiia [Language education principles of learning Ukrainian Sign language: monograph]. Kyiv: Interservice. (in Ukrainian)

Kulbida, S. (2019c). Ukrainska mova. 2 klas: pidruchnyk dlya 2 klasu spetsialnyh zakladiv zagalnoi serednyoi osvitu (H 91) [Ukrainian language. Grade 2: Textbook for Grade 2 Special General Secondary Education (H 91)]. Kyiv: Lybid. (in Ukrainian)

Kulbida, S. (2019d). Ukrainska mova. 2 klas: pidruchnyk dlya 2 klasu spetsialnyh zakladiv zagalnoi serednyoi osvitu (H 90) [Ukrainian language. Grade 2: Textbook for Grade 2 Special General Secondary Education (H 90)]. Kyiv: Lybid. (in Ukrainian)

Kulbida, S., Chepchina I., Adamyuk, N., Zamsha, A., Zborovska, N., Ivanyusheva, N. \& Leshchenko, L. (2011). Kontseptsiya bilingvalnogo navchannya osib z porushennyamy sluhu [The concept of bilingual training for people with hearing impairments]. Kyiv: UTOG. (in Ukrainian)

Lokshyna, O. (2019). Yevropeyska dovidkova ramka klyuchovyh kompetentnostey dlya navchannya vprodovzh zhyttya: onovlene bachennya 2018 roku [European reference framework of key competences for lifelong learning: an updated 2018 version]. Ukrainskyy pedagogichnyy zhurnal, 3, 21-30. https://doi.org/10.32405/2411-1317-2019-3-21-30 (in Ukrainian)

Mazepova, O. (2014). Evolyutsiya ponyattya "Movna osobystist" u suchasnyh lingvistychnyh doslidzhennyah [The evolution of "language personality" concept in modern linguistic researches]. Movni i kontseptualni kartyny svitu, 48, 274-286. (in Ukrainian)

Milano, E. (2006). Personality Factors in Spoken Discourse. Encyclopedia of Language \& Linguistics (Second Edition), 312-313

Omelchuk, S. (2019). Suchasna ukrainska lingvodydaktyka: normy $v$ terminologii $i$ movna praktyka fahivtsiv: monografiia [Contemporary Ukrainian Language Education: norms in terminology and language practice of specialists: monograph]. Kyiv: Publishing house «Kyyevo-Mogylyanska Akademiya». (in Ukrainian)

Pentylyuk, M. (2011). Formuvannja movnoi osobystosti uchnya - vazhlyva problema suchasnoi lingvodydaktyky [The formation of the linguistic personality of the student is an important problem of modern language education]. Aktyalni problemy suchasnoi lingvodydaktyky: zbirnyk statey, 57-63. (in Ukrainian)

Postanova Kabinetu Ministriv Ukrainy "Pro zatverdzhennya Polozhennya pro spetsialnu shkolu ta Polozhennya pro navchalno-reabilitatsiynyy tsentr" (2019) [Resolution of the Cabinet of Ministers of Ukraine "On Approval of the Regulations on the Special School and the Regulations on the Training and Rehabilitation Center"]. Retrieved from https:// zakon.rada.gov.ua/go/221-2019-п

Rosch, E. \& Lloyd, B. (1978). Cognition and Categorization. Hillsdale, NJ: Lawrence Erlbaum Publisher 
Savchenko O. (2015). Uminnya vchytysya - klyuchova kompetentnist molodshogo shkolyara: posibnyk [The ability to learn as a key competency of a junior student: a textbook]. Kyiv: Pedagogichna dumka. (in Ukrainian)

Sedov, K. (2004). Diskurs i lichnost: evolyutsiya kommunikativnoy kompetentsyi [Discourse and personality: the evolution of communicative competence]. Moskva: Labirint. (in Russian)

Seligei, P. (2012). Movna svidomist: struktura, typologiya, vyhovannya [Language awareness: structure, typology, education]. Kyiv: Publishing house «Kyyevo-Mogylyanska Akademiya». (in Ukrainian)

Selivanova, O. (2016). Suchasna lingvistyka: terminologichna entsyklopediya [Modern linguistics: a terminological encyclopedia]. Poltava: Dovkillya-K. (in Ukrainian)

Struganets, L. (2012). Ponyattya "movna osobystist" v ukrayinistytsi [The concept of "linguistic personality" in Ukrainian studies]. Kultura slova, 77, 127-133. (in Ukrainian)

Valencia, J. \& Cenoz, J. (2010). The role of bilingualism in foreign language acquisition: Learning English in the Basque country. Journal of Multilingual and Multicultural Development, 13(5), 433-449. http://doi.org/10.1080/01434632.1992.9994507

Vynogradov, V. (1980). O yazyke hudozhestvennoy prozy [About the language of fiction]. Moskva: Nauka. (in Russian)

Weisgerber, J. L. (2009). Native language and spirit formation. Moskva. (in Russian)

Yermolenko, S. \& Matsko, L. (1995). Navchalno-vyhovna kontseptsiya vyvchennya ukrainskoi (derzhavnoi) movy [The educational concept of studying the Ukrainian (state) language]. Pochatkova shkola, 1, 35-37. (in Ukrainian)

Zakon Ukrainy "Pro zabezpechennya funktsionuvannya ukrainskoi movy yak derzhavnoi" (2019) [Law of Ukraine "On ensuring the functioning of the Ukrainian language as a state language"]. Retrieved from https://zakon.rada.gov.ua/laws/show/2704-19

Zalevska, A. (2007). Vvedeniye v psiholingvistiku [Introduction to psycholinguistics]. Moskva: Russian State University for the Humanities. (in Russian)

Zasyekina, L. (2007). Movna osobystist v suchasnomu sotsialnomu prostori [A linguistic personality in today's social space]. Sotsialna psyhologiya, 5, 82-89. (in Ukrainian) 